\title{
SEAWOMIR RAUBE
}

(Białystok)

\section{ZAGADNIENIE PEWNOŚCI WIEDZY I WIARY W REFLEKSJI JOHNA LOCKE'A I SAMUELA CLARKE'A}

Intencją Samuela Clarke’a było to, aby racjonalna etyka, którą zamierzał sformułować, potwierdziła przy pomocy naturalnego światła rozumu to, co głosi chrześcijaństwo w zakresie moralnych zobowiązań, cnót, występków i wad. Te dwa porządki miały być paralelne; to znaczy, twierdzenia etyki religijnej nie powinny stanowić składników argumentacji racjonalno-etycznych, konkluzje tych ostatnich natomiast mają pokazywać prawomocność tych pierwszych. Perspektywa refleksji Clarke'a wyznaczona jest następującymi kwestiami: Czy objawienie chrześcijańskie w żadnym swoim segmencie nie przeczy rozumowi? Co w konfrontacji z racjonalnymi ustaleniami okazuje się w doktrynie moralnej chrześcijaństwa zgodne z rozumem? I czy cała wizja objawiona mieści się w ramach wyznaczonych przez naturalny rozum, a wobec tego, czy są w doktrynie chrześcijańskiej twierdzenia sprzeczne z jasnym i wyraźnym poznaniem rozumowym?

Według filozofa zasadniczym celem wiary jest zmiana ludzkich postaw, zgodnie z kanonem prawd chrześcijańskich. W tej wizji Bóg stwarza świat i nieprzerwanie nim kieruje i rządzi; i „nadzoruje ze szczególną uwagą moralne czyny ludzi” ${ }^{1}$. Ale wobec tego, że boska opieka roztacza się nad wszystkimi stworzeniami, nasuwa się pytanie, dlaczego na świecie jest tyle zepsucia, o czym angielski filozof

\footnotetext{
1 Samuel Clarke, A Discourse concerning the Unchangeable Obligations of Natural Religion, and the Truth and Certainty of the Christian Revelation (dalej jako Discourse), w: tenże, A Discourse concerning the Being and Attributes of God, the Obligations of Natural Religion, and the Truth and Certainty of the Christian Revelation, London 1732, s. 336. Wydanie to orócz A Discourse obejmuje A Demonstration of the Being and Attributes of God, najbardziej znane dzieło Clarke'a.
} 
zresztą wielokrotnie wspomina? I po co w ogóle Bóg przemawia do człowieka objawiając mu swoją wolę w sposób nadnaturalny, skoro powinien mówić poprzez rozum, który jest boskim wyposażeniem jednostki ludzkiej mającym być właściwym i wystarczającym naturalnym narzędziem odszyfrowywania zamiarów i oczekiwań Stwórcy? Głos rozumu musi więc być z konieczności (faktycznej) uznany za niedostatecznie przekonujący. Ale skoro rozbrzmiewa głos objawiony, to czy i on nie jest wystarczająco jasny? Te pytania wyłaniają się w kontekście Clarke’a wizji chrześcijaństwa wyraźnie szczególnie tam, gdzie mówi on o potrzebie nadnaturalnej pomocy objawienia, o bezpośredniej interwencji Boga. $\mathrm{W}$ istocie jest to przynajmniej częściowa rezygnacja z racjonalistycznej próby sformułowania etyki i powrót do punktu widzenia wiary.

Pisze Clarke, że niektórzy filozofowie przedchrześcijańscy dokładnie diagnozowali stan zepsucia, dominacji zmysłowych pragnień, pokazywali jego przyczyny; ale byli także świadomi, że filozofia mówiąca językiem rozumu jest ostatecznie bezsilna wobec zadania zmiany świata i ludzkich postaw; dlatego byli oni głęboko przekonani, że tylko siła boskiej interwencji może dokonać tego dzieła ${ }^{2}$.

Jaką pewność daje nam w płaszczyźnie moralnej objawienie? To pytanie obecne było w brytyjskiej debacie zanim Clarke przystąpił do sformułowania swoich koncepcji i długo jeszcze po ukazaniu się jego dzieł. Czy pewność zdobyta na drodze poznania rozumowego daje większą pewność niż objawienie? Czy ranga chrześcijańskiej moralności płynącej z nadprzyrodzonego źródła nie ulega obniżeniu już tylko przez to, że się ją konfrontuje ze źródłem naturalnego rozumu? Niezdecydowanie Clarke'a co do kierunku czysto racjonalnej argumentacji etycznej i przyjęcie teologicznej tezy o niepodważalności objawienia to raczej skutek gromadzenia się filozoficznych trudności bądź obawa przed zajęciem stanowiska deistycznego.

Inny wielki brytyjski moralista późniejszej generacji, Joseph Butler (1692-1752), takich rozterek nie miał, choć był anglikańskim biskupem Durham. Stanowiska Clarke'a i Butlera są w tej kwestii podobne, ale nie identyczne. Bardziej radykalny jest tu Butler, a przynajmniej wczesny Butler. Chrześcijańskie objawienie na gruncie filozofii moralności jest rzecz jasna istotne, ale nie stanowi ostatecznej instancji rozstrzygającej pytania etyczne. W pierwszej fazie swojej twórczości, przed opublikowaniem w 1736 r. The Analogy of Religion, Natural and Revealed, to the Constitution and Course of Nature (Porównanie religii naturalnej $i$ objawionej do konstytucji $i$ biegu natury), Butler sądził, że najważniejsze etyczne pojęcia można zrozumieć niezależnie od treści objawionych, to znaczy na drodze samego rozumu. Decydującym składnikiem jego wczesnych kazań (wyda-

2 Discourse, s. 331. 
nych w wyborze jako Fifteen Sermons upon Human Nature, or Man considered as a Moral Agent w 1726 r.) było przeświadczenie, że przesądzający jest głos sumienia. A sumienie przemawiało do człowieka także zanim ogłoszona została chrześcijańska Dobra Nowina, dlatego poganie mogli żyć według wskazań cnoty i obowiązków prawa moralnego tak samo jak chrześcijanie. Chrześcijaństwo nie przekreśliło tego wiecznego prawa, a tylko je uzupełniło nowymi powinnościami oraz wzorem etycznym Chrystusa ${ }^{3}$.

Ale już w Analogy of Religion Butler występuje otwarcie przeciw deistom. Broni chrześcijaństwa w ten sposób, iż ukazuje intelektualne prawdopodobieństwo, jakie dostrzec trzeba, gdy się doktrynę religijną bezstronnie analizuje. Intelektualne prawdopodobieństwo to nie pewność co prawda, ale też inne dziedziny naszego poznawczego zainteresowania nie poddają się ujęciom charakteryzującym się całkowitą pewnością. Innymi słowy, według Butlera bezwzględna pewność to ideał, którego nie jesteśmy w stanie osiągnać w jakiejkolwiek dziedzinie poznania, z wyjątkiem, być może, nauk matematycznych. Trudności związane z wiedzą religijną są analogiczne do trudności wyłaniających się w wiedzy naturalnej. Wiedzy o naturze nie umiemy ani objąć całościowo, ani w sposób niewątpliwy, pełno w niej pytań bez przesądzających odpowiedzi; a chociaż rozum formułuje różne sugestie, wszystkie one pozostają jednak hipotezami różniącymi się poziomem prawdopodobieństwa. I pomimo tych trudności związanych z naszym poznaniem natury deiści przyjmują twierdzenie, iż Bóg jest stwórcą tej nie do końca dającej się wyjaśnić intelektualnie rzeczywistości wszechświata. Zatem nie są wcale w lepszej sytuacji niż chrześcijanie; są w sytuacji analogicznej. Twierdzenia deistów mają podobną prawomocność co twierdzenia chrześcijan: nie zawsze oparte są na dowiedzionej podstawie. To oznacza, że wiedza religijna nie jest nieracjonalna, skoro wiedza naturalna (pełna luk i niejasności) nie jest traktowana w podobny sposób, jako nieracjonalna. Poza tym przeświadczenia wchodzące w zakres wiary nadprzyrodzonej nie są przeświadczeniami o czysto teoretycznym charakterze; wprost przeciwnie, dotyczą spraw dla człowieka najżywotniejszych, rozstrzygają bowiem na swój sposób, czy jesteśmy nieśmiertelni, co nas czeka po życiu doczesnym, czy będziemy nagrodzeni, czy będziemy ukarani etc. Odnoszą się więc do tego, co ma znaczenie doniosłe - praktycznie i życiowo. Jak pisze Butler, „analogia z naturą wykazuje, że nie możemy oczekiwać żadnych korzyści, gdy nie użyjemy do ich uzyskania czy utrzymania odpowiednich środków. Rozum nie wskazuje nam żadnych bezpośrednich środków do uzyskania dobrodziejstw doczesnych czy duchowych.

3 Maria Ossowska pisząc o wczesnej fazie twórczości Butlera stwierdza: „Rola chrześcijaństwa w moralności jest u naszego autora w jego kazaniach określona w sposób, który usprawiedliwia włączenie go do deistów"; Myśl moralna Oświecenia angielskiego, Warszawa 1966, s. 215. 
Musimy więc uczyć się bądź z doświadczenia, bądź z objawienia. Ale rozważany przypadek wyklucza doświadczenie" 4.

Obrona niesprzeczności chrześcijańskiej doktryny z paradygmatem racjonalności sprowadza się zatem do tego, że wiedza pozareligijna, uchodząca za zgodną z takim paradygmatem, ukazana jest jako również niewolna od niedostatecznych uzasadnień i w niektórych swoich fragmentach niekonkluzywna. Natomiast, że taka obrona nie jest całkowicie przekonująca, przyznaje sam Butler pisząc: „Przyznaję bez wahania, że powyższy traktat nie jest zadowalający i bardzo mu do tego daleko" 5 . Jednak zarzut zaadresowany do deistów, a sformułowany przy pomocy metody deistycznej, okazał się bardzo nośny. Jak pisze Copleston, „wielka siła dzieła Butlera bierze się z jego świadomości roli, jaką odgrywa prawdopodobieństwo w interpretacji natury i w naszym postępowaniu, w sprawach doczesnych, oraz z jego argumentacji, zgodnie z którą winniśmy wobec tego kierować się prawdopodobieństwem również w sprawach religii, nie domagając się usunięcia wszystkich trudności i niejasności" 6 .

Wcześniej kwestię tę, rozpalającą w myśli brytyjskiej niezwykle gorące spory, podjął John Locke w Rozważaniach dotyczacych rozumu ludzkiego. W nowożytnej filozofii europejskiej źródła tego zagadnienia tkwią w kartezjańskiej koncepcji wiedzy oraz oczywistości jako kryterium prawdy. Aczkolwiek Descartes bezpośrednio do zagadnienia prawomocności wiedzy religijnej się nie odnosił, jednak jego rozstrzygnięcia w zakresie epistemologii stały się na długo punktem odniesienia dla innych zagadnień, bezpośrednio bądź nie wprost związanych z kwestią prawdziwości poznania, w tym także w dziedzinie filozoficznych dyskusji na temat relacji między wiedzą naturalną a nadprzyrodzoną.

4 Joseph Butler, The Analogy of Religion, Nataural and Revealed, to the Constitution and Course of Nature; w: Works, t. 1, Oxford 1896, s. 201; cyt. za F. Copleston, Historia filozofii, t. V, przeł. Jarosław Pasek, Warszawa 1997, s. 186.

5 Tamże, s. 363; cyt. za F. Copleston, Historia filozofii, t. V, wyd. cyt., s. 186.

6 F. Copleston, Historia filozofi, t. V, wyd. cyt., s. 188. Butler od opublikowania Analogy of Religion staje się pod względem apologetycznym podobny do Clarke'a, choć pozbawiony jest tej radykalnej emfazy polemicznej, która towarzyszyła twórczości Clarke’a. Taką oto charakterystykę dojrzałego Butlera (po ukazaniu się właśnie Analogy...) kreśli Maria Ossowska: „Praca ta, opublikowana w 1736 r., należy już do drugiej fazy w biografii Butlera, fazy, w której był już biskupem anglikańskim, cieszącym się względami głów koronowanych. Był to, podobno, już wtedy człowiek zupełnie odmienny od Butlera - młodego kaznodzei, który w 1726 r. (a więc o rok później, niż ukazały się Rozważania Hutchesona) ogłosił piętnaście kazań, wybranych spośród licznych innych, wygłaszanych w ciągu lat ośmiu w jednej z kaplic Londynu"; Myśl moralna Oświecenia angielskiego, wyd. cyt., s. 212. 
Uderzającą cechą myśli nowożytnej jest to, że prawie cała spuścizna scholastyczna została zepchnięta z głównej sceny filozoficznej, dlatego nie znajdziemy u czołowych filozofów XVII i XVIII wieku odwołań do np. św. Tomasza, u którego kwestia ta jest jedną z centralnych.

Chociaż Clarke bezpośrednio do Locke’a się nie odwoływał, nie ulega wątpliwości, że cenił jego dzieła, a w filozofii moralnej, w której chciał ukazać wzajemne dopasowanie etyki racjonalnej i moralnej doktryny chrześcijańskiej, autor Rozważań był obecny domyślnie jako zasadnicza inspiracja całego przedsięwzięcia, przedsięwzięcia, którego zasadniczym celem miała być obrona wiary i etyki religijnej przy pomocy środków filozofii racjonalnej.

Locke starał się uporządkować w świetle zasad empiryzmu wzajemne relacje rozumu (wiedzy) i wiary, pojętej jako to, co pretenduje do uznania za prawdziwe, czyli co jest także jakimś rodzajem wiedzy, choć rodzajem innej natury. Zinterpretowanie wiary w taki sposób, jako intelektualnego aktu aprobaty dla treści przedstawianych jako nadprzyrodzone, uzasadniało poddanie jej procedurom racjonalnego sprawdzania. Gdyby bowiem wiarę pojmować jako to, co może być całkowicie odmienne bądź jawnie niezgodne z naszym przyrodzonym poznaniem ${ }^{7}$, wiedza religijna mogłaby wówczas przybierać postać przeświadczeń najdziwniejszych i najbardziej fantastycznych; tak dalece wiara taka odbiegałaby od naszej wiedzy ugruntowanej w doświadczeniu naturalnym i intelektualnej refleksji, iż „człowiek myślący”, analizując przeświadczenia religijne, mógłby się tylko zdumiewać „ich szaleństwem i uważać, że te rzeczy są tak dalekie od tego, by mogły się podobać wielkiemu i mądremu Bogu, iż nie może on nie sądzić, iż są śmieszne i odrażające dla człowieka o trzeźwym umyśle" 8 . Locke nie przeciwstawia więc rozumu i wiary wykluczająco, ale tak, aby można było ustalić, czy i co jest w prawdach religijnych podstawą ich powszechnej akceptacji ${ }^{9}$. Dokonując tego rozgraniczenia Locke sądzi, że poznanie oparte na

7 „Nie mogę tedy pojąć - pisze Locke - jak ci, którzy czynią objawienie wyłącznym przedmiotem wiary, mogą mówić, iż jest sprawą wiary, a nie rozumu, czy takie a takie zdanie, znajdujące się w takiej a takiej księdze, pochodzi z natchnienia bożego, jeśli nie zostało objawione, że owo zdanie albo wszystkie zdania zawarte w tej księdze zostały nam przekazane z bożej inspiracji. Bez takiego objawienia przypisanie lub odmówienie autorytetu boskiego jakiemuś zdaniu czy jakiejś księdze nigdy nie może być sprawą wiary, lecz tylko rozumu, i to taką, że do uznania tej rzeczy za prawdę muszę dojść jedynie odwołując się do rozumu, który nigdy nie może domagać się ode mnie czy dawać mi możność wiary w to, co jest mu przeciwne: rozum bowiem nie może sprawić, bym przyjął za prawdę to, co mu się przedstawia jako nierozumne"; J. Locke, Rozważania dotyczace rozumu ludzkiego, przeł. B. J. Gawecki, Warszawa 1955, IV.18.6, t. II, s. $451-452$.

8 Tamże, IV.18.11, s. 456.

9 Rozum i wiarę Locke definiuje w następujący sposób: „Otóż tutaj przyjmuję, że rozum, jako różny od wiary i jako jej przeciwieństwo, to odkrywanie pewności albo prawdopodobieństwa takich zdań czy prawd, do jakich umysł dochodzi ma drodze dedukcji, wyprowadzając je z idei, 
intuicji i dedukcji bądź doświadczeniu zmysłowym przynosi jednak większą pewność; przeświadczenia objawione pozostają mimo to w pewnych kontekstach interpretacyjnych wiarygodne, albowiem rozum nie mogąc orzec jednoznacznie o ich prawdziwości bądź fałszywości nie uznaje ich po prostu za bezsensowne, a tylko za takie sądy, które przynależą do pozarozumowej dziedziny, dziedziny wiary, czyli tego, co określane jest często jako wiedza religijna. Dotyczy to takich sytuacji, gdy świadectwom objawienia (czy mówiąc ściślej: świadectwom, które uchodzą za świadectwa objawione) przeciwstawiają się prawdopodobne domysły rozumu, czyli że świadectwa te skonfrontowane z rozumem nie mogą wykazać się bezwzględną pewnością ${ }^{10}$. Ale nawet wówczas rozum nie może być zwolniony z obowiązku analizowania, czy to, czemu dajemy pierwszeństwo przed jakimś mniemaniem, istotnie jest objawieniem ${ }^{11}$.

Charakterystyczny fragment konstatacji Locke'a z księgi czwartej Rozważan, pokazujący skrótowo ogólną istotę jego podejścia do objawienia jako takiego, brzmi następująco: „Wszystko, co Bóg objawił, z pewnością jest prawdziwe, i nie można mieć co do tego wątpliwości. To jest właściwy przedmiot wiary; rozum jednak musi osądzić, czy coś jest, czy nie jest objawieniem bożym; a rozum nigdy nie może zezwolić na to, byśmy odrzucali większą oczywistość dla czegoś, co jest mniej oczywiste, ani też byśmy przekładali prawdopodobieństwo nad wiedzę i pewność. To, że jakieś objawienie tradycyjne w tym brzmieniu, w jakim je nam

które zdobył, używając naturalnych swych władz poznawczych, to znaczy: przez doznania zmysłowe lub refleksję. Z drugiej strony wiara jest uznaniem za prawdę takiego zdania, które nie powstało przez dedukcję rozumową, lecz zostało przyjęte dzięki zaufaniu do tego, kto je przedkłada, jako pochodzące od Boga i przekazane drogą nadnaturalną. Taki sposób odkrywania ludziom prawd nazywamy objawieniem"; tamże, IV.18.2, s. 445.

10 Pisze o tym Locke tak oto: „Po pierwsze, każde zdanie objawione, o którego prawdziwości umysł nic orzec nie może z pomocą swych przyrodzonych zdolności i pojęć, jest wyłącznie przedmiotem wiary"; i nieco dalej o możliwej kolizji twierdzeń objawienia ze zdaniami, którym przysługuje prawdopodobieństwo: „Gdzie bowiem zasady rozumu nie wykazały w sposób oczywisty, że samo zdanie jest na pewno prawdziwe albo błędne, tam może rozstrzygać jasne objawienie, jako odmiennego rodzaju zasada prawdziwości i podstawa uznania za prawdziwe; i zdanie takie może tu być sprawą wiary, a więc pozostawać poza zasięgiem rozumu. W tej bowiem sprawie szczególnej rozum nie mógł wyjść poza pewien stopień prawdopodobieństwa; i tam, gdzie zawiódł rozum, a objawienie wskazywało, po której stronie znajduje się prawda, tam decyduje o rzeczy wiara"; tamże, IV, 18, 9, s. 454-455.

11 „Umysł nie może wszak być pewien prawdziwości tego, czego nie poznaje w sposób oczywisty, i kieruje się tylko prawdopodobieństwem, jakie sam widzi; nie może przy tym nie uznać za prawdę tego, co ma za sobą takie świadectwo, które w jego przekonaniu pochodzi od Tego, kto ani mylić się nie może, ani zwodzić nie chce. Jednak i wtedy jest rzeczą rozumu sądzić o tym, czy owo świadectwo jest naprawdę objawieniem i co znaczą słowa, w jakich zostało podane"; tamże, IV.18.8, s. 453. Jednakże filozof angielski sugeruje (w różnych fragmentach), że pewności co do tego, że coś jest naprawdę przez Boga objawioną treścią, nie osiągniemy nigdy; przy czym, gdy zdanie objawione jest sprzeczne z jasnym sądem rozumu, zdania takiego nie uznajemy za objawione; ale nie możemy być pewni, że jest zdaniem objawionym takie zdanie, które jest niezgodne z zaledwie mniemaniem; choć formalnie powinniśmy zdanie objawione w tym ostatnim przypadku uznać za wiarygodne. 
podano, i w tym znaczeniu, w jakim je przyjmujemy, jest pochodzenia boskiego, nie może być tak oczywiste ani tak jasne i pewne, jak oczywiste są zasady rozumu. Żadna więc rzecz, która się sprzeciwia temu, co jasno i oczywiście dyktuje rozum, i której z tym nie można pogodzić, nie ma prawa uchodzić za przedmiot wiary i domagać się uznania jako prawda, której rozumowi kwestionować nie wolno. Lecz wszystkiemu, co jest bożym objawieniem, należy się pierwszeństwo nad wszelkimi naszymi mniemaniami, uprzedzeniami, przesądami i interesami; ma ono prawo do tego, byśmy je przyjmowali, w pełni uznając je za prawdę" 12 .

W tym miejscu warto odwołać się do skrupulatnej analizy Zbigniewa Ogonowskiego, ukazującej poglądy Johna Locke'a na ten temat ${ }^{13}$. W Rozważaniach filozof mówi o objawieniu tradycyjnym i bezpośrednim (pierwotnym). Objawienie tradycyjne jest przekazywaniem prawd, które Bóg oznajmił wybranym ludziom i które przekazywane są „w tradycji piśmiennej lub ustnej” ${ }^{14}$ przy pomocy słów „oraz zwykłymi drogami przekazywania naszych przedstawień” ${ }^{15}$. Zasadniczym elementem tego rodzaju objawienia wydaje się dla Locke'a Pismo Święte. Objawienie tradycyjne nie dostarcza nam nowej wiedzy naturalnej, opartej na ideach prostych zdobywanych na drodze doznania zmysłowego lub refleksji; jeśli objawienie przemawia do nas w sposób komunikowalny, musi być oparte na tym, co znamy już z doświadczenia; nie poszerza zatem wiedzy; jeśli objawienie operowałoby treściami wykraczającymi poza idee proste, byłoby niekomunikowalne, to znaczy nie byłoby elementem wiedzy, a jedynie wiary, pojętej jako to, co ponad rozumem.

Po drugie, prawdzie objawienia tradycyjnego nie może przysługiwać taki stopień pewności jak poznaniu przyrodzonemu, ponieważ treści objawienia nie są wynikiem takich procesów, dzięki którym pewność można osiągnąć, a mianowicie w wyniku bezpośredniego świadectwa zmysłów bądź intuicji i dedukcji.

Po trzecie, także objawienie pierwotne (bezpośrednie) ${ }^{16}$, będące wynikiem doświadczenia nie naturalnego a mistycznego, musi podlegać sprawdzeniu przez

\footnotetext{
12 Tamże, IV, 18.10 , s. 455.

13 Zob. Zbigniew Ogonowski, Locke, Warszawa 1972, ss. 294-296.

14 J. Locke, Rozważania..., IV.18.6, wyd. cyt., s. 451.

15 Tamże, IV.18.3, s. 447.

16 Locke charakteryzuje oba typy objawienia w następujący sposób: „Co się zatem tyczy naszych idei prostych, które są podstawą i jedynym materiałem wszelkich naszych pojęć i naszej wiedzy, to musimy polegać wyłącznie na swym rozumie, chcę przez to powiedzieć: na swych zdolnościach przyrodzonych, i nigdy nie możemy zdobyć ich, nawet pewnych spośród nich, przez tradycyjne objawienie. Mówię przez objawienie tradycyjne, aby je odróżnić od objawienia pierwotnego. Przez jedno rozumiem pierwszą impresję, jaką wraził bezpośrednio Bóg w umysł człowieka, i tu nie możemy ustalić żadnych granic; przez drugie rozumiem te impresje, które przekazuje się innym w słowach oraz zwykłymi drogami przekazywania naszych przedstawień"; tamże, IV, 18,3 , s. 447.
} 
naturalny rozum, albowiem twierdzenie, że Bóg coś komuś komunikuje, nie jest doświadczeniem w dosłownym znaczeniu, a ponadto należy mieć pewność, iż to objawienie pochodzi istotnie od Boga. Ale nawet w takiej sytuacji należy badać racjonalnie, czy treści objawione w ten sposób nie przeczą jasnemu świadectwu własnego rozumu. A że poznanie uzyskane drogą nadprzyrodzoną nie może osiągnąć pewności równej tej, jaką daje nam poznanie intuicyjne, przeto nie można przyjmować za prawdę przeświadczeń, które są sprzeczne z jasnym i wyraźnym rozumem ${ }^{17}$. Powoływanie się na takie objawienia bezpośrednie często prowadzi do urojeń i fantazji.

Jak pisze Z. Ogonowski, z rozważań Locke'a wynika, że jasność i wyraźność, jakie przysługują poznaniu rozumowemu, nigdy nie będą cechować treści wiary; a w takim razie konkluzją ostateczną jest to, że „Również w religii nie wolno uznać za prawdę niczego, co sprzeczne jest z naszym jasnym i wyraźnym poznaniem rozumowym, ono bowiem zapewnia najwyższą pewność, jaka jest osiągalna dla człowieka" 18 . Oznacza to, że rozum może weryfikować, czy to, co pretenduje do rangi bożego objawienia, jest nim istotnie; czy też, dlatego, że jest jawnie sprzeczne z regułami racjonalnego sensu, pozostaje niczym więcej jak tylko przesądem.

Locke nie odnosił się przy tym do żadnej konkretnej kwestii teologicznej chrześcijaństwa, stosując, jak się wydaje, ostrożny unik, aby nie popaść w tarapaty, jakie były udziałem wielu ówczesnych myślicieli wchodzących w konflikt z prawowierną dogmatyką. W 1696 roku uchwalona została represyjna ustawa przeciw bluźnierstwu (Blasphemy Law), która umożliwiała ściganie i karanie przez instytucje państwowe autorów uznanych za zbyt kontrowersyjnych, to znaczy podważających dogmaty chrześcijaństwa sprowadzające się do artykułów wiary Kościoła anglikańskiego. Wydaje się, że bezpośrednią inspiracją do tego rozwiązania legislacyjnego były obrazoburcze teksty Charlesa Blounta oraz Christianity not Misterious (Chrześcijaństwo bez tajemnic) Johna Tolanda, które ukazało się drukiem także w $1696 \mathrm{roku}^{19}$. Chociaż Rozważania Locke opublikował przed tą datą, bo w 1690 roku, to przecież napięcia religijne, które doprowadziły

17 Zob. tamże, IV.18.5, s. 449. Nieco dalej Locke pisze: „Żadnego przeto zdania nie można uznać za objawienie boskie i zdobyć dlań uznania, należnego każdemu takiemu objawieniu, jeśli jest ono sprzeczne z naszym jasnym intuicyjnym poznaniem"; tamże, IV.18.5, s. 449. Jeszcze bardziej stanowczo stwierdza: „Daremne więc byłoby narzucać jako przedmiot wiary twierdzenia, które przeczą jasnemu postrzeżeniu zgodności albo niezgodności naszych idei. Ani z tego, ani z żadnego innego tytułu nie mogłyby zdobyć naszego uznania, bo wiara nigdy nie jest zdolna przekonać nas o czymś, co jest sprzeczne z naszą wiedzą"; tamże, IV.18.5, s. 450.

18 Z. Ogonowski, Locke, wyd. cyt., s. 296.

19 Zob. Maria Ossowska, Myśl moralna Oświecenia angielskiego, wyd. cyt., s. 130. Zresztą wpływ teorii wiedzy Locke'a na tekst Tolanda jest bezsporny, choć potępiony oficjalnie został tylko Toland, a nie Locke; zob. David Berman, The Irish Freethinker (esej dołączony do wydania Tolanda Christianity...), w: John Toland's Christianity not Mysterious. Text, Associated Works and Critical Essays, ed. P. McGuinness, A. Harrison, R. Kearney, Dublin 1997, s. 224-225. 
do uchwalenia tej restrykcyjnej ustawy, wypełniały życie publiczne w Anglii od dawna, w czym Locke także miał swój udział, jako zwolennik porzucenia ortodoksyjnych schematów.

Zgodnie z koncepcją prawd koniecznych, wyrażoną przez Locke'a w anonimowo wydanym Liście o tolerancji ${ }^{20}$, ważne dla zbawienia są nieliczne prawdy, które zrozumiałe są dla wszystkich. W Rozważaniach... taką prawdą jest istnienie Boga (IV, 10.6), nieśmiertelność ludzka (IV.18.7), natomiast w Racjonalności chrześcijaństwa (Reasonableness of Christianity) wymieniona jest jako jedyna prawda konieczna do zbawienia ${ }^{21}$ - mesjańska rola Jezusa, bez rozstrzygnięcia, czy autor ma na myśli także jego boskość. Wszystkie inne prawdy, poza koniecznymi, są nieistotne dla zbawienia; nie mają więc żadnego znaczenia, poza może znaczeniem niejako negatywnym, polegającym na wywoływaniu konfliktów religijnych.

Przy okazji warto zauważyć, że nie podejmuje Locke w jakimkolwiek kontekście zagadnienia Trójcy; nie wymienia go wśród prawd ponadrozumowych, co czyniono na ogół w takich wyszczególnieniach, ani tym bardziej wśród prawd sprzecznych z rozumem, jako że Locke pisał o sprawach posiadajacych kontekst teologiczny z najwyższą ostrożnością, tak by zachować pozory dogmatycznej poprawności. Jednak w tej sprawie nie uniknął zarzutu socynianizmu, także w kontekście problematyki Trójcy ${ }^{22}$, a po opublikowaniu Racjonalności chrześcijaństwa (anonimowo) został zaatakowany i nazwany wprost „rabinem z Rakowa” przez teologa Johna Edwardsa w pamflecie Socynianizm zdemaskowany (Socinianism Unmasked) ${ }^{23}$.

Locke starał się zatem nie dyskredytować otwarcie chrześcijańskiego objawienia w całości i nie odbierać mu jakiegokolwiek prawdopodobieństwa. Zgodnie z jego koncepcją epistemologiczną, chrześcijańskie objawienie nie należy do zakresu wiedzy w sensie ścisłym, ale należy do dziedziny mniemania. A to oznacza, że przesądzić prawdziwości objawienia nie jesteśmy w stanie przy pomocy jakichkolwiek metod poznania naturalnego, analogicznie do tego, co czynimy z twierdzeniami odwołującymi się do empirii lub wiedzy demonstratywnej. Ta konkluzja mogła być czytelna dla najbardziej wyczulonych strażników wiary, ale na ogół nie uważano jej za obrazoburczą, szczególnie że środowiska ortodoksyjnej teologii po przesileniach Chwalebnej Rewolucji nie miały już takiego wpływu jak poprzednio.

Istnieją wszakże w Rozważaniach... takie fragmenty, które świadczyć mogą o tym, że Locke jak gdyby wbrew własnym ustaleniom akceptuje całkowitą pewność prawd objawionych. Pisząc o cudach stwierdza, że ich niezwykłość, polega-

20 Zob. Z. Ogonowski, Locke, wyd. cyt., s. 297.

21 Zob. tamże, s. 306.

22 Zob. tamże, s. 299.

23 Zob. tamże, s. 300. 
jąca na całkowitej odmienności od normalnego biegu natury, nie zmniejsza naszej akceptacji dla relacji o takich zdarzeniach, a przeciwnie, im większa nadnaturalność opisywanych zdarzeń, tym większa nasza dla nich pewność, o ile tylko relacje o nich są dobrze poświadczone. Zdarzenia takie odnoszą się bowiem do działań Stwórcy podejmowanych w wymiarze natury, który dla siebie tylko wiadomych celów postanawia dokonać takiej cudownej ingerencji. I analogicznie wszystkim prawdom objawionym przysługuje „najwyższy stopień uznania”. Pisze Locke o tym tak oto: „Poza zdaniami, o jakich dotychczas była mowa, jest jeszcze jeden rodzaj, który domaga się najwyższego stopnia naszego uznania na podstawie samego świadectwa, bez względu na to, czy rzecz przedłożona zgadza się czy nie zgadza z potocznym doświadczeniem i zwykłym biegiem rzeczy. A to dlatego, że świadectwo pochodzi od Tego, kto ani sam nie zwodzi, ani zwodzony być nie może, to znaczy od samego Boga. Z takim świadectwem łączy się pewność wolna od wszelkich wątpliwości i oczywistość nie znająca wyjątku. To świadectwo nosi swoistą nazwę objawienia, a nasze uznanie tego świadectwa nazywa się wiarą; działa ona tak bezwzględnie na nasz umysł i tak całkowicie wyłącza wszelkie wahanie, jak właściwa nasza wiedza; o prawdziwości objawienia, które pochodzi od Boga, nie moglibyśmy wątpić tak samo, jak wątpić nie możemy o własnym istnieniu" ${ }^{24}$.

Zatem w prawdy objawienia wątpić niepodobna i nie sposób wahać się w uznaniu ich całkowitej pewności. Pomimo tego, że, z drugiej strony, należą one do dziedziny sądów tylko prawdopodobnych? Według Locke'a sądy prawdopodobne, czyli mniemania, charakteryzują się różnym stopniem prawdopodobieństwa; zależny jest on od tego, jak dalece zdarzenia, o których sądy są wypowiadane, odbiegają od typowego, codziennego przebiegu zjawisk oraz tego, jakiego rodzaju świadectwami są świadectwa uwiarygodniające te zdarzenia: czy te świadectwa są ugruntowane w doświadczeniu, i jak bardzo w czasie są oddalone. Zatem w świetle tej koncepcji prawdy objawione nie powinny zasługiwać na mocne uznanie, ponieważ tylko w minimalnym stopniu (jeśli w ogóle) spełniają kryteria wysokiego prawdopodobieństwa. Locke pisze jednak, jak widzieliśmy, że w treści objawienia wątpić nie możemy. I dodaje zaraz po tym wyznaniu stwierdzenie, które w istocie stawia pod znakiem zapytania ( $\mathrm{w}$ istocie nierozstrzygalnym) racjonalną prawomocność objawienia. Pisze bowiem: „Ale musimy być pewni, że jest to istotnie objawienie boże i że je właściwie pojmujemy; inaczej bowiem narazilibyśmy się na wszelakie wybryki fanatyzmu i na wszelkie błędy, jakie płyną z fałszywych zasad, gdybyśmy wiarę i poczucie pewności wiązali z czymś, co nie jest boskim objawieniem" ${ }^{25}$. Wobec tego konkluzja Locke'a to, co pretenduje do rangi bycia

24 Locke, Rozważania..., IV.16.14, wyd. cyt., s. 410-411.

25 Tamże, IV.16.14, s. 411. 
rzeczywistym głosem Boga, ostatecznie pozostawia poza granicami wiedzy, której przysługuje pewność i racjonalna prawomocność.

To była najbardziej niepokojąca dla ówczesnych teologów wymowa dzieła angielskiego myśliciela. Jak pisze Zbigniew Ogonowski, niewidoczny wprost sens Rozważań sprowadzał się do tego, że „Objawieniu, które pochodzi od Boga, musimy bezwzględnie wierzyć. Jest to oczywiste. Ale przedtem musimy wiedzieć, że objawienie to istotnie od Boga pochodzi. Wiedzieć zaś nie możemy i nigdy nie będziemy mogli; możemy snuć tylko mniej lub bardziej prawdopodobne przypuszczenia. Niestety, jeśli chodzi o objawienie chrześcijańskie, to w świetle kryteriów, na których jedynie możemy się opierać przy procedurze weryfikacji, sądom na temat jego wiarygodności przysługuje stopień prawdopodobieństwa bardzo znikomy" 26.

Był to dla teologii wniosek zarówno kontrowersyjny, jak i destrukcyjny.

$$
* * *
$$

U Clarke'a nie znajdziemy takich wyraźnych rozgraniczeń na wiedzę pewną i prawdopodobną, rozum i wiarę, objawienie i poznanie, jak w myśli Locke'a. Samuel Clarke zakłada, że rozum i wiara są ze sobą zgodne, o ile poznanie rozumowe przebiega poprawnymi logicznie drogami, o ile argumentowanie nie jest zakłócone przez namiętności. Dla Clarke’a wiara graniczy z oczywistością. Rozum jest również prawomocnym źródłem wiedzy, pod warunkiem jednak, że jego ustalenia nie kolidują z twierdzeniami religijnymi. Mówiąc inaczej, postawa Clarke'a (w Discourse concerning the Unchangeable Obligations of Natural Religion, and the Truth and Certainty of the Christian Revelation) jest w kwestii moralności, wiary, objawienia i rozumu postawą teologa, nie filozofa, który za przesłankę oczywistą przyjmuje chrześcijańską doktrynę etyczną; i próbuje pokazać, że żadnej sprzeczności między doktryną a rozumowym rozpoznaniem twierdzeń moralnych nie ma i być nie może. Jednak jego argumentacje bardziej przypominają arbitralne i asertywne konstatacje, na ogół niepowiązane w ciągi uzasadnień, niż filozoficzno-logiczne rozumowania. (Bardziej przejrzysty logicznie i mniej chaotyczny jest Clarke w Demonstration of the Being and Attributes of God). W porównaniu z Locke'iem uderzający jest brak przejrzystości, a często także brak spójności, choć także autor Rozważań nie uchodzi za myśliciela konsekwentnego.

Przyglądając się krytycznej diagnozie stanu moralności społecznej, jaką kreśli Clarke, można dojść do przekonania, iż uważa on, że ludzkość prawie powszechnie została zdominowana przez rozmaite wady moralne, wśród których znajdują się

26 Z. Ogonowski, Locke, wyd. cyt., s. 304. 
bezbożność i nikczemność. Jeśli do takich występków dochodzi w sytuacji, gdy objawienie jest znane, to czy nie świadczy to o jego słabej sile?

A jednak nie. Pisze Clarke, choć brzmi to jak paradoks, że mimo wszystko w krajach chrześcijańskich poziom moralny jest wyższy niż w pogańskich: prawdziwsze wyobrażenia Boga i Jego atrybutów, głębsze poczucie różnicy między dobrem a złem, większe zrozumienie dla zobowiązań i intensywniejsze oczekiwanie życia po śmierci ${ }^{27}$. To wszystko jest zasługą wiary - chrześcijańskiej, wynikiem stopniowej przebudowy moralnej praktyki za sprawą świadectwa Chrystusa ${ }^{28}$. Niektórzy filozofowie antyczni mieli jasną świadomość, że ukazanie powszechnego stanu zepsucia i prawdziwej kondycji człowieka jest warunkiem koniecznym, ale nie wystarczającym; Platon, na którego powołuje się Clarke, w Prawach (ks. 1) i w Fedonie pokazuje, że reguły ludzkiego postępowania „muszą pochodzić z niebios" 29. Ale samo objawienie ich przez rozum, bez głosu Boga, jest w kształtowaniu porządku moralnego nieskuteczne. To dało pogańskim myślicielom „racjonalną podstawę do oczekiwania i nadziei" na objawienie „z niebios" 30. A zatem, twierdzi Clarke, nawet pogańscy filozofowie przeczuwali i zapowiadali objawienie Chrystusa.

Objawienie „tradycyjne”, by użyć w tym miejscu pojęcia Locke'a, jest dla Clarke'a zakresowo zgodne całkowicie z wiedzą dającą się uzyskać na podstawie rozumu. Jeśli pisze on o oczywistości wiary, zgodnej z rozumem, ma na myśli całą wiarę chrześcijańską wyrażoną w doktrynie. Albowiem „Jest wystarczająco oczywiste, że ludzie nie są powołani do wiary w zasady religii chrześcijańskiej bez dostatecznej racjonalnej podstawy" 31. Wobec tego wiara jako coś irracjonalnego, jako „credo quia absurdum”, jest dla Clarke'a perspektywą najzupełniej obcą i szkodliwą ${ }^{32}$. Jest bowiem przeciwnie; Bóg dowody prawd chrześcijańskich okazuje w naturze rzeczy. A jeśli Bóg tak czyni, znaczy to, że jest to w najwyższym stopniu rozumne i celowe. Jak więc człowiek, obdarzony rozumem, mógłby uchylić się od zaakceptowania tych świadectw, a przede wszystkim świadectwa nauczania Jezusa i racjonalnego ujęcia istoty występku i cnoty?

Objawienie jest potwierdzeniem tego, do czego udawało się dochodzić niektórym filozofom starożytnym; ale jest też „koniecznym” uzupełnieniem i rozszerzeniem naszej wiedzy o oczekiwaniach Boga, czyli o obowiązkach. Bez tego trudno

\footnotetext{
27 Discourse, s. 313.

28 Tamże, s. 312.

29 Tamże, s. 309.

30 Tamże, s. 306.

31 Tamże, s. 446.

32 Pisze wyraźnie, że nie należy przeciwstawiać wiary i rozumu, a tym bardziej nie należy przyjmować wiary li tylko „z tej racji, iż jest ona nieprawdopodobna ”; Discourse, s. 446.
} 
byłoby odkryć np., w ramach jakiego kultu ma się dokonywać oddawanie czci dla Boga, jakiej ekspiacji oczekuje od grzeszników Najwyższy Prawodawca ${ }^{33}$. Do tego naturalny rozum sam, bez boskiej asysty, dojść by nie mógł, co pokazują przypadki tych filozofów, którzy najdalej zaszli na drodze odkrycia boskiego porządku, a to przypadek Platona czy Cycerona, albowiem dla człowieka ,jest potrzebna niezwykła i nadnaturalna pomoc" 34 .

Gdzie upatruje Clarke podstaw oczywistości wiary, dzięki której nie ma miejsca na „dwuznaczności i wątpliwości” 35? Najprościej powiedzieć można, że ją po prostu zakłada, to znaczy postrzega ją jako coś, czego nie można zakwestionować. Syntetyzując liczne wypowiedzi filozofa można wskazać na następujące aspekty, do których Clarke się odwołuje mówiąc o oczywistości wiary. Po pierwsze, autorytet naturalnego światła rozumu; po drugie, świadectwa faktów ( „najbardziej oczywiste"), czyli porządek przyrody; po trzecie, ludzki lęk przed siłą wyższą; i wreszcie po czwarte, autorytet Pisma Świętego ${ }^{36}$.

Łatwo zauważyć, że koncepcja oczywistości Clarke’a przypomina pogląd Kartezjusza. Tak jak w przypadku francuskiego myśliciela znajdujemy tu podobne tezy główne i te same słabości. Kryterium prawdy stanowi oczywistość; sprowadzona jest ona jednak do subiektywnego poczucia oczywistości, co stanowi zarazem o słabości koncepcji, wprowadza bowiem dowolność do uznania tego, co prawdziwe. Tak jak Descartes również Clarke nie wskazuje na sposób, dzięki któremu można odróżnić to, co oczywiste od tego, co tylko się takie wydaje. W istocie kryterium oczywistości staje się w koncepcjach tego rodzaju narzędziem, które można stosować z dużą dozą subiektywnej arbitralności, co widzimy bardzo dokładnie w refleksji angielskiego filozofa i moralisty. Jak pisze Kołakowski w odniesieniu do doktryny kartezjańskiej, w ujęciach ewidentystycznych pojawia się idealistyczny wątek „uzależniający uznanie czegokolwiek za prawdę od czyjegokolwiek poczucia słuszności, w więc uprawomocnia wszelkie przekonanie ludzkie, jeśli tylko towarzyszy mu podmiotowa wiara w jego oczywistość" 37.

Przyjrzyjmy się każdej z tych odpowiedzi Clarke’a. W jaki sposób autorytet rozumu wskazuje na niemożliwość zaprzeczenia treści objawienia? I skąd rozum czerpie autorytet, skoro tak często błądzi? Apologetyczna sugestia Clarke’a jest tu taka oto: rozum jest miarodajnym środkiem poznania, ale tylko wtedy, gdy naturalne rozpoznanie rzeczywistości pokrywa się z religijnymi przeświadczeniami

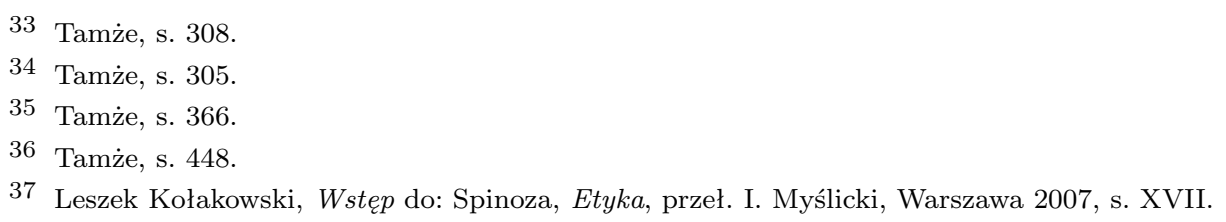


objawienia, to znaczy, kiedy rozum jest zgodny z treścią wiary. A jeśli tak, to można stwierdzić, że podstawą autorytetu rozumu jest wiara objawiona, która w ramach jak gdyby sprzężenia zwrotnego jest przez tak zdefiniowany rozum potwierdzana. Ujęcie Clarke'a przypomina w znacznej mierze rozstrzygnięcie Tomasza z Akwinu.

Przy okazji można zauważyć, że strategia obrony stosowana w religiach objawionych bardzo często sprowadza się do tego, że wykazuje się, iż ludzki umysł nie jest w stanie wyjaśnić rzeczywistości nie przyjmując racji istnienia tej rzeczywistości. Tą racją jest „pierwszy poruszyciel”, „byt konieczny”, „pierwsza przyczyna”, „wieczny projektodawca” itd. Inaczej mówiąc, sugeruje się w takich przypadkach, że bez założenia istnienia bytu boskiego nie potrafimy wyjaśnić świata, czyli że tak jest skonstruowany nasz umysł, iż musimy przyjąć istnienie Boga. Ale wykazywana racja to nie Bóg objawienia, Bóg osobowy. Mimo to, przerzuca się pomost między jednym a drugim najwyższym bytem (rozumu i objawienia), uznając, że „filozoficzny” Bóg jest potwierdzeniem „objawionego” Boga. U Clarke’a znajdujemy taką skłonność apologetyczną również. Broni on chrześcijaństwa objawionego w Starym i Nowym Testamencie odwołując się do twierdzeń rozumowych. A one mogą co najwyżej dowodzić, że istnieje jakaś siła wyższa, Bóg, o którym powiedzieć można niewiele, a nie Bóg, o którym mówi Pismo.

Wymieniliśmy także porządek przyrody jako podstawę oczywistości wiary. To jest zrozumiałe w kontekście kogoś takiego jak Clarke, kto był zafascynowany „nową fizyką”. W tym zakresie problemowym koncepcje Clarke'a są odwzorowaniem poglądów Newtona, dla którego prawa fizyki to reguły funkcjonowania rzeczywistości - ustanowione przez wszechmocnego Boga, „Pantokratora”. Dlatego mechanika świata nasuwa oczywisty wniosek co do jego Autora; dla Clarke’a „Bóg fizyki Newtona" to zarazem Stwórca, o którym mówi wiara objawiona. Zatem oczywistość wiary znajduje podstawę nie w tym, co może uchodzić za niepowątpiewalne (reguły fizyki są wszak empirycznymi uogólnieniami), ale w arbitralnym ustanowieniu boskiego sprawstwa regularności świata.

Natomiast lęk przed Bogiem Clarke rozumie psychologicznie, jako wewnętrzną obawę przed gniewem siły wyższej w kontekście działań budzących wewnętrzne rozterki; chodzi także o lęk przed żywiołami przyrody, które uznajemy za dziedzinę manifestacji ponadprzyrodzonej mocy. Jednakże Clarke nie mówi tu o jakiejś jeszcze niezidentyfikowanej boskości, tylko z góry zakłada, że chodzi o gniew Boga osobowego, Boga tradycji judeo-chrześcijańskiej. Skąd jednak wiemy, iż żywimy obawę przed gniewem istoty przedstawianej w chrześcijańskiej tradycji, a nie przed gniewem Boga rozumianego filozoficznie jako Absolut, tego Clarke nie wyjaśnia; inaczej, jaką mamy pewność, że w żywiole wichury bądź powodzi przemawia właśnie Bóg Biblii? To jest założenie również przyjęte przez filozofa angielskiego z góry: przyjmuje on, że wszelki lęk, wewnętrzny czy płynący 
z otaczającej przyrody, związany jest z istotą boską. A jeśli mówi o istocie boskiej, to zawsze tylko o takiej, jaką zna tradycja chrześcijańska, mianowicie o boskiej istocie osobowej.

Nie mniej arbitralnie obchodzi się Clarke z twierdzeniem, że oczywistość wiary wynika z autorytetu Pisma Świętego. Autorytet ten polega na tym, iż stanowi manifestację głosu Boga, a głos Boga musi z konieczności posiadać range najwyższą. Zatem objawiona wiara jest (i musi być) oczywista. Może się tu jednak wyłonić Locke'owskie pytanie, na jakiej podstawie uznajemy, że głos Boga jest odzwierciedlony w chrześcijańskim objawieniu. Odpowiedź Clarke'a jest arbitralnym założeniem, że inaczej po prostu być nie może. Wobec tego, brzmi konkluzja Clarke'a, „powód niewiary musi być inny niż rzekomy brak wystarczającej oczywistości" 38 .

Co więcej, objawienie Chrystusa, przekazywane przez Ewangelie, zawiera oczywistość nie mniejszą niż Stary Testament, że oto jedyny i realnie istniejący Bóg przemawia przez Pismo. Pisze Clarke, że ta oczywistość, pomimo czasowego oddalenia wydarzeń biblijnych, jest nawet większa niż ta, która towarzyszy nam czasami w sprawach codziennych. Nauczanie Jezusa i wypowiedzi apostołów to długo oczekiwana przez starożytnych moralistów siła, która jako jedyna potrafiła wpoić ludziom potrzebę nie tylko wiedzy o sprawach ostatecznych, ale i pragnienie przemiany, filozoficzna spekulacja bowiem to za mało, aby do takich zmian doprowadzić $^{39}$. Świadectwo Ewangelii jest boską odpowiedzią na niesamowystarczalność światła natury i naturalnego rozumu, na moralne zepsucie, na wątpliwości dotyczące sprawiedliwego osądu istot ludzkich w życiu przyszłym; dzięki objawieniu Jezusa rozum ponownie może rozpoznawać boże zamiary co do ludzi i świata i jest w stanie adekwatnie ujmować bezbożność i nieprawość ${ }^{40}$. A chrześcijaństwo jest jedyną taką religią. Pisze Clarke: „Nie istnieje inna religia w dzisiejszym świecie poza chrześcijaństwem, która posiada właściwą podstawę czy wyraźny przejaw rozumu, by być takim boskim objawieniem. Zatem gdyby chrześcijaństwo nie było prawdziwe, nie byłoby objawienia boskiej woli uczynionego w stosunku do gatunku ludzkiego" 41.

Przy okazji omawiania tego zagadnienia filozof oświadcza, że jedną z największych zasług „odnowionego" czy powtórnego ujawnienia woli bożej jest „ponowne

\footnotetext{
38 Discourse, s. 448.

39 Tamże, s. 304.

40 Tamże, s. 332.

41 Tamże, s. 155. Przy okazji koncepcji nagród i kar pisze Clarke, że owa słabość pierwotnie doskonałego światła rozumu pojawiła się wskutek jakiegoś grzesznego kataklizmu, o którym nic powiedzieć człowiek nie jest w stanie, z wyjątkiem tego, czego się dowiaduje z Pisma. Clarke ma zapewne na myśli Upadek, ale podchodzi do tej biblijnej opowieści oględnie; to jest objaw pewnego dystansu wobec teologii kalwińskiej, wpływowej w Anglii w czasach Clarke’a.
} 
odkrycie rozumnej części boskiego stworzenia" 42 (istoty ludzkiej), potwierdzenie unii człowieka i Boga, ale także zapewnienie o nagrodach i karach czekających po śmierci, co Clarke nazywa „największą inspiracją religii” 43. Jednakowoż w kontekście poglądu wyrażanego gdzie indziej, że spoczywające na nas obowiązki są niejako niezależne od przyszłej odpłaty, należy uznać, że jest to co najmniej objaw niekonsekwencji.

Teologiczna postawa Clarke'a w kwestiach dogmatycznych jest całkowicie zgodna z ortodoksyjnym nauczaniem Kościoła anglikańskiego - z wyjątkiem kwestii Trójcy. Widać to wyraźnie w jego analizie centralnego dogmatu chrześcijaństwa, jakim jest Wcielenie. I choć nie pisze wprost o boskości Jezusa, to nie ma podstaw do wątpliwości, że całkowicie ją akceptuje w aspekcie faktycznym i nie sprowadza jej tylko do wymiaru społecznej korzyści ${ }^{44}$. Dogmat o Wcieleniu jest dla Clarke'a najlepiej dostosowaną do celów prawdziwej religii nauką, „trudno wyobrazić sobie lepszą doktrynę" 45; to jest prawdziwy dowód miłości i miłosierdzia Boga-Stwórcy, to że posyła swojego „,jednorodzonego syna”, aby przyjął naszą ludzką naturę i w jej ramach objawił rodzajowi ludzkiemu wolę Boga. A objawienie Chrystusa w nadprzyrodzony sposób potwierdza to, co rozum naturalny ustalić może; aczkolwiek „pewne prawdy nie mogą być odkryte przy pomocy światła rozumu" 46.

Ostatecznie zatem Samuel Clarke, inspirowany początkowo Locke'owską obietnicą „racjonalności chrześcijaństwa”, przemawia jak teolog, zaniepokojony niespójnością między doktryną religijną a schematami interpretacji racjonalnej.

\footnotetext{
42 Discourse, s. 327.

43 Tamże, s. 307.

44 Inaczej niż Locke i Newton, którzy uważali, każdy w inny sposób, że nie ma aż tak wielkiego znaczenia, czy Chrystus był Synem Bożym, najistotniejsze jest bowiem etyczne (mesjańskie) przesłanie Jezusa.

45 Discourse, s. 367.

46 Tamże, s. 314. W tym kontekście mówi Clarke o wybaczaniu za grzechy i ekspiacji; tego nie możemy być pewni, jak i tego, jakiej skruchy oczekuje od grzesznika Bóg, ponieważ „tego nie umiemy wywnioskować z atrybutów Boga"; tamże, s. 295.
} 